\title{
Detection of CTX-M-15 harboring Escherichia coli isolated from wild birds in Tunisia
}

\author{
Houssem Ben Yahia', Rym Ben Sallem', Ghassan Tayh', Naouel Klibi', Insaf Ben Amor ${ }^{1}$, Haythem Gharsa ${ }^{1,2}$, \\ Abdellatif Boudabbous ${ }^{1}$ and Karim Ben Slama ${ }^{1,2^{*}}$ (iD
}

\begin{abstract}
Background: The spreading of antibiotic resistant bacteria is becoming nowadays an alarming threat to human and animal health. There is increasing evidence showing that wild birds could significantly contribute to the transmission and spreading of drug-resistant bacteria. However, data for antimicrobial resistance in wild birds remain scarce, especially throughout Africa. The aims of this investigation were to analyze the prevalence of ESBLproducing E. coli in faecal samples of wild birds in Tunisia and to characterize the recovered isolates.

Results: One hundred and eleven samples were inoculated on MacConkey agar plates supplemented with cefotaxime $(2 \mu \mathrm{g} / \mathrm{ml})$. ESBL-producing E. coli isolates were detected in 12 of 111 faecal samples (10.81\%) and one isolate per sample was further characterized. $\beta$-lactamase detected genes were as follows: bla $a_{\mathrm{CTX}-\mathrm{M}-15}$ (8 isolates), bla $a_{\mathrm{CTX}-\mathrm{M}-15}+b_{1} a_{\mathrm{TEM}-1 \mathrm{~b}}$ (4 isolates). The ISECP1 and orf477 sequences were found respectively in the regions upstream and downstream of all bla $a_{\mathrm{CTX}-\mathrm{M}-15}$ genes. Seven different plasmid profiles were observed among the isolates. IncF (FII, FIA, FIB) and IncW replicons were identified in 11 CTX-M-15 producing isolates, and mostly, other replicons were also identified: IncHI2, IncA/C, IncP, Incl1 and IncX. All ESBL-producing E. coli isolates were integron positive and possessed "empty" integron structures with no inserted region of DNA. The following detected virulence genes were: (number of isolates in parentheses): fimA (ten); papC (seven); aer (five); eae (one); and papGIII, hly, cnf, and bfp (none). Molecular typing using pulsed-field gel electrophoresis and multilocus sequence typing showed a low genetic heterogeneity among the 12 ESBL-producing strains with five unrelated PFGE types and five different sequence types (STs) respectively. CTX-M-15-producing isolates were ascribed to phylogroup A (eleven isolates) and B2 (one isolate).
\end{abstract}

Conclusion: To our knowledge, this study provides the first insight into the contribution of wild birds to the dynamics of ESBL-producing E. coli in Tunisia.

Keywords: Escherichia coli, ESBL, Molecular characterization, Integrons

\section{Background}

Escherichia coli (E. coli) is a facultatively anaerobic Gram-negative bacteria belonging to Enterobacteriaceae family [1]. E. coli is ubiquitous organisms that is found in soil, water, and vegetation and is part of the normal intestinal flora of human and animals. This intestinal bacterium acquires antimicrobial resistance faster than other conventional microorganism and is considered as a significant indicator for the selective pressure generated by antibiotic use [2,3].

\footnotetext{
* Correspondence: karim.benslama@fst.rnu.tn

${ }^{1}$ Laboratoire des Microorganismes et Biomolécules actives, Faculté des Sciences de Tunis, Université de Tunis El Manar, 2092 Tunis, Tunisie ${ }^{2}$ Institut Supérieur des Sciences Biologiques Appliquées de Tunis, Université de Tunis El Manar, 2092 Tunis, Tunisie

Extended spectrum $\beta$-lactamases (ESBL) are rapidly spreading in the last few years. CTX-M-15 is one of the most widespread ESBL types reported in many regions of the world. The association of $b l a_{\mathrm{CTX}-\mathrm{M}-15}$ gene with successful bacterial clones and epidemic plasmids is strongly implicated in its worldwide dissemination. CTX-M-15 production, which has been mainly identified in human and veterinary clinical samples, has occurred recently in wild animals, including wild birds, as well as in several environmental samples [4-15]. Besides resistance to extended-spectrum cephalosporins, ESBLproducing E. coli exhibit additional resistances to various antibiotics classified by the WHO as "critically important to human health" such as fluoroquinolones and aminoglycosides [16]. The spread of resistance to these 
antimicrobial classes in wildlife is therefore an alarming global health threat.

Tunisia is one of many countries with higher rates of bacterial pathogens with ESBLs-producers in the clinical setting, mostly associated with CTX-M-types [17]. Many previous studies have already been done by our research group about resistance mechanisms of $E$. coli isolates collected from different origins (human, animal, water and food chain), provided a great understanding of resistance evolution in different Tunisian environments. CTX-M-15 is the most predominant ESBL variant identified among clinical E. coli isolates in Tunisia, while CTX-M-1 enzymes has been identified in $E$. coli isolated from pets, food animals, healthy humans, foods, soil and water [6, 18-25]. Moreover, similarities between ESBLproducing $E$. coli collected from poultry, pets and human have been demonstrated by sequence typed results, highlighting the close connection between resistant isolates from different sources [19]. Although the occurrence and diversity of ESBL producing $E$. coli isolates from multiple sources in Tunisia has been well documented, data on antibiotic resistance in wild environmental reservoirs are limited. Furthermore, there is still a lack of information on the prevalence and characteristics of ESBLs producing $E$. coli isolates from wild birds in Africa. The purpose of this study was to evaluate the carriage level of ESBL-positive E. coli isolates in wild birds in Tunisia and to characterize their encoding genes in order to correlate data with previously obtained information from various sources in Tunisia.

\section{Methods}

\section{Sample processing and susceptibility testing}

One hundred eleven faecal samples were collected during March to mid-June 2012 from wild birds. Details of sampling including the establishment of the species origin of droppings and isolated sites, has been described in a last work [26], and summarized in Table 1. Avian fecal material (one per individual) were first cultured in Luria-Bertani (LB) broth for 16 to $20 \mathrm{~h}$ at $37^{\circ} \mathrm{C}, 1 \mu \mathrm{l}$ broth was then inoculated onto MacConkey agar plates supplemented with cefotaxime (CTX, $2 \mu \mathrm{g} / \mathrm{mL})$. After incubation at $37{ }^{\circ} \mathrm{C}$ for $24 \mathrm{~h}$, colonies showing E. coli morphology were recovered, identified by classical biochemical methods and by speciesspecific PCR (amplification of uidA gene) [25]. All cefotaxime-resistant $E$. coli isolates were screened for ESBL phenotype by double disk test [27]. One ESBL-producing $E$. coli isolate per positive sample was further characterized. Susceptibility to 17 antimicrobials agents was tested by disk-diffusion method [27]. Antibiotics tested were as follows: ampicillin, cefoxitin, ceftazidime, cefotaxime, imipenem, colistin, gentamicin, amikacin, tobramycin, streptomycin, nalidixic acid, ciprofloxacin, sulphonamides, trimethoprim-sulfamethoxazole, tetracycline, rifampicin,
Table 1 Number and origin of faecal samples

\begin{tabular}{|c|c|c|}
\hline Birds species & & $\begin{array}{l}\text { Number of } \\
\text { faecal samples }\end{array}$ \\
\hline \multirow[t]{4}{*}{ Resident birds } & $\begin{array}{l}\text { European goldfinch } \\
\text { (Carduelis carduelis) }\end{array}$ & 17 \\
\hline & $\begin{array}{l}\text { European greenfinch } \\
\text { (Carduelis chloris) }\end{array}$ & 35 \\
\hline & $\begin{array}{l}\text { Pigeon } \\
\text { (Columba livia) }\end{array}$ & 7 \\
\hline & $\begin{array}{l}\text { European serin } \\
\text { (Serinus serinus) }\end{array}$ & 7 \\
\hline \multirow[t]{5}{*}{ Migratory birds } & $\begin{array}{l}\text { African river martin } \\
\text { (Pseudochelidon eurystomina) }\end{array}$ & 10 \\
\hline & $\begin{array}{l}\text { Herring gull } \\
\text { (Larus argentatus) }\end{array}$ & 11 \\
\hline & $\begin{array}{l}\text { Common blackbird } \\
\text { (Turdus merula) }\end{array}$ & 9 \\
\hline & $\begin{array}{l}\text { Gray gull } \\
\text { (Leucophaeus modestus) }\end{array}$ & 7 \\
\hline & $\begin{array}{l}\text { European bee-eater } \\
\text { (Merops apiaster) }\end{array}$ & 8 \\
\hline
\end{tabular}

and chloramphenicol. E. coli ATCC 25922 was used as a control strain.

\section{Molecular typing and phylogenetic analysis of $E$. coli isolates}

The clonal relationship among the cefotaxime resistant isolates was determined by pulsed-field gel electrophoresis (PFGE) using XbaI [28, 29]. All isolates were analyzed by MLST. Allelic profiles of these isolates were obtained after internal fragment sequencing of seven housekeeping genes ( $a d k$, fum $C, \operatorname{gyr} B, i c d, m d h$, purA, $\operatorname{rec} A$ ). Sequences Types (ST) were determined and compared with those included in the database (mlst.ucc.ie/ $\mathrm{mlst} / \mathrm{dbs} / \mathrm{ecoli}$ ) [30]. The isolates were allotted to the phylogenetic groups A, B1, B2, or D using a triplex PCR assay with specific primers for $c h u A$, yjaA and TspE4.C2 markers as previously reported [31].

\section{Serotyping and virulence genotyping of $E$. coli isolates} All isolates were screened for O25b and O157 serotypes and for afa/dra operon [32, 33]. The detection of specific virulence factors including $s t x$, fimA, papG allele III, $h l y A, c n f 1$, papC, aer, eae, and bfp was performed by PCR. Primers and PCR conditions were used as previously described [34].

\section{Resistance genotype of $E$. coli isolates}

DNA extraction was performed for all the strains by boiling. Specific detection of beta-lactamases genes was determined by PCR and sequencing for the following genes: $b l a_{\mathrm{CTX}-\mathrm{M}}, b l a_{\mathrm{TEM}}, b l a_{\mathrm{SHV}}, b l a_{\mathrm{OXA}}$ and $b l a_{\mathrm{CMY}}$. The genetic environments surrounding $b l a_{\mathrm{CTX}-\mathrm{M}}$ was characterized by PCR [35]. The presence of genes associated with resistance to tetracycline, sulphonamides, 
gentamicin and quinolones were determined as previously described $[23,29,36-41]$. Target genes and primers were summarized in Table 2. For the detection of chromosomal mutations, quinolone resistancedetermining regions (QRDR) of the gyrA and parC, genes were amplified and sequenced. QRDR nucleotide sequences were compared with the reference sequences of the E. coli K-12 strain (GenBank accession no. U00096) [42]. Specific PCR was used to detect the intI1 and intI2 genes which encodes respectively for class 1 and class 2 integrases [29]. The variable regions of class 1 and class 2 integrons were characterized by PCR and sequencing in all intI1- or intI2-positive isolates. The presence of qacED1-sul1 genes in the $3{ }^{\prime}$-conserved segment of class 1 integrons was also investigated in all intI1-positive isolates [29, 43]. All PCR assays were

Table 2 Primers of the target antimicrobial resistance genes

\begin{tabular}{|c|c|c|c|}
\hline $\begin{array}{l}\text { Resistance } \\
\text { genes }\end{array}$ & Primer sequence $\left(5^{\prime}-3^{\prime}\right)$ & $\begin{array}{l}\text { Size } \\
(\mathrm{pb})\end{array}$ & Reference \\
\hline \multirow[t]{2}{*}{ tetA } & F:GTAATTCTGAGCACTGTCGC & \multirow[t]{2}{*}{937} & \multirow{10}{*}{$\begin{array}{l}\text { Sáenz, et al, } \\
2004 \text { [29] }\end{array}$} \\
\hline & R:CTGCCTGGACAACATTGCTT & & \\
\hline \multirow[t]{2}{*}{ tet $B$} & F:CTCAGTATTCCAAGCCTTTG & \multirow[t]{2}{*}{416} & \\
\hline & R:CTAAGCACTTGTCTCCTGTT & & \\
\hline \multirow[t]{2}{*}{ sul1 } & F:TGGTGACGGTGTTCGGCATTC & \multirow[t]{2}{*}{789} & \\
\hline & R:GCGAGGGTTTCCGAGAAGGTG & & \\
\hline \multirow[t]{2}{*}{ sul2 } & F:CGGCATCGTCAACATAACC & \multirow[t]{2}{*}{722} & \\
\hline & R:GTGTGCGGATGAAGTCAG & & \\
\hline \multirow[t]{2}{*}{ sul3 } & F:CATTCTAGAAAACAGTCGTAGTTCG & \multirow[t]{2}{*}{990} & \\
\hline & R:CATCTGCAGCTAACCTAGGGCTTTGGA & & \\
\hline \multirow[t]{2}{*}{$\operatorname{aac}(3)-11$} & F:ACTGTGATGGGATACGCGTC & \multirow[t]{2}{*}{237} & \multirow{4}{*}{$\begin{array}{l}\text { Van de } \\
\text { Klundert et al } \\
1993 \text { [36] }\end{array}$} \\
\hline & R:CTCCGTCAGCGTTTCAGCTA & & \\
\hline \multirow[t]{2}{*}{$\operatorname{aac}(3)-I V$} & F:CTTCAGGATGGCAAGTTGGT & \multirow[t]{2}{*}{286} & \\
\hline & R:TCATCTCGTTCTCCGCTCAT & & \\
\hline \multirow[t]{2}{*}{ qnrA } & F:AGAGGATTTCTCACGCCAGG & \multirow[t]{2}{*}{580} & \multirow{2}{*}{$\begin{array}{l}\text { Cattoir et al, } \\
2007[37]\end{array}$} \\
\hline & R:TGCCAGGCACAGATCTTGAC & & \\
\hline \multirow[t]{2}{*}{ anrB } & F:GATCGTGAAAGCCAGAAAGG & \multirow[t]{2}{*}{469} & \multirow{2}{*}{$\begin{array}{l}\text { Wang et al, } \\
2008 \text { [39] }\end{array}$} \\
\hline & R:ACGATGCCTGGTAGTTGTCC & & \\
\hline \multirow[t]{2}{*}{ qnrs } & F:GCAAGTTCATTGAACAGGGT & \multirow[t]{2}{*}{550} & \multirow{2}{*}{$\begin{array}{l}\text { Cattoir et al, } \\
2007[37]\end{array}$} \\
\hline & R:TCTAAACCGTCGAGTTCGGCG & & \\
\hline \multirow[t]{2}{*}{ qepA } & F:GCAGGTCCAGCAGCGGGTAG & \multirow[t]{2}{*}{617} & \multirow{4}{*}{$\begin{array}{l}\text { Rocha-Gracia } \\
\text { et al, } 2010 \\
\text { [38] }\end{array}$} \\
\hline & R:GGACATCTACGGCTTCTTCG & & \\
\hline \multirow[t]{2}{*}{$a a c\left(6^{\prime}\right)-1 b$} & F:TTGCGATGCTCTATGAGTGGCTA & \multirow[t]{2}{*}{482} & \\
\hline & R:CTCGAATGCCTGGCGTGTTT & & \\
\hline \multirow[t]{2}{*}{ gyrA } & F:TACACCGGTCAACATTGAGG & \multirow[t]{2}{*}{648} & \multirow{2}{*}{$\begin{array}{l}\text { Oram and } \\
\text { Fisher, } 1991 \\
\text { [41] }\end{array}$} \\
\hline & R:TTAATGATTGCCGCCGTCGG & & \\
\hline parc & F:AAACCTGTTCAGCGCCGCATT & 395 & Vila et al, \\
\hline & R:GTGGTGCCGTTAAGCAAA & & \\
\hline
\end{tabular}

performed with positive controls of the Microorganisms and Active Biomolecules Lab collection.

\section{Plasmid characterization}

Plasmids from all strains were assigned to the incompatibility groups using PCR-based replicon typing (PBRT) [44].

\section{Results}

Cefotaxime resistant $E$. coli isolates were detected in 12 out of 111 avian faecal materials analyzed (10.81\%). The twelve fresh droppings were collected in Northern Tunisia and were recovered from the following free-living birds (number/area): European serin (five/ Bizerte), Goldfinches (two/ Bizerte), Greenbirds (two/ Bizerte), Harring Gulls (one/Bizerte), Bee-eaters (one/ Menzel Bouzelfa) and Goldfinches (one/ Menzel Bouzelfa) (Table 3).

All CTX ${ }^{\mathrm{R}}$ E. coli isolates exhibited an ESBL phenotype and expressed the CTX-M-15 enzyme. Four isolates coexpressed CTX-M-15 and TEM-1 enzymes.The ISEcp1 and orf477 sequences were identified upstream and downstream of all bla $a_{\mathrm{CTX}-\mathrm{M}-15}$ genes.

All the twelve ESBL-positive isolates contained class 1 integrons with no inserted gene cassettes. No class 2 integrons was detected among the tested isolates. The CTX-M-15-positive E. coli also harbored genes encoding resistance to tetracycline [tet $A$ ], to quinolones [qnrA, $q n r B$ and $\left.a a c\left(6^{\prime}\right)-\mathrm{Ib}-\mathrm{cr}\right]$, to sulphonamides [sul3] and to gentamicin $[a a c(3)-\mathrm{II}]$.

The screening for Plasmid-Mediated Quinolone Resistance (PMQR) determinants among the 12 CTXM-15-producing E. coli showed the presence of qnrB1+ $q n r A 1+a a c-\left(6^{\prime}\right)-I b-c r$ in 5 isolates, $q n r B 1+q n r A 1$ genes in 3 isolates, qnrB1+aac-(6')-Ib-cr in 1 isolate and qurB1 in 1 isolate. No mutations were found in the QRDRs of either DNA gyrase or topoisomerase.

Eleven of the twelve ESBL-positive isolates corresponded to the A phylogenetic group. The other isolate corresponded to the B2 group (Table 3).

Pulsed-field gel electrophoresis analysis demonstrated five different pulsotypes among the 12 ESBL-positive strains. Eight strains showed an identical PFGE pattern and were assigned to the same new sequence type (Table 3). These strains with an identical genetic backgrounds were recovered in the same sampling site from different free-living birds including European serin $(n=3)$, Green birds $(n=2)$, Goldfinches $(\mathrm{n}=2)$, and Harring Gulls $(n=1)$. Three CTX-M-15-producing isolates had different PFGE profiles and were typed as ST297/A, ST410/A, and ST349/B2.

The fimA gene was the most commonly found among the 9 target virulence-associated genes and was detected in all strains. The $p a p C$ and aer virulence genes were present in seven and five isolates respectively. The eae gene, 
Table 3 Characteristics of the twelve extended-spectrum beta-lactamase (ESBL)-positive Escherichia coli isolates recovered from the faecal samples of birds

\begin{tabular}{|c|c|c|c|c|c|c|c|c|c|c|}
\hline $\begin{array}{l}\text { E. coli } \\
\text { isolates }\end{array}$ & Species & $\begin{array}{l}\text { Region of } \\
\text { the sample }\end{array}$ & $\begin{array}{l}\text { Virulence } \\
\text { factors }\end{array}$ & Phylogroup & $\begin{array}{l}\text { ESBL and genetic } \\
\text { environment }\end{array}$ & $\begin{array}{l}\text { Resistance } \\
\text { phenotype } \\
\text { to non-beta-lactam } \\
\text { antibiotics }\end{array}$ & $\begin{array}{l}\text { Other resistance } \\
\text { genes detected }\end{array}$ & Replicons & PFGE & MLST \\
\hline CbR33 & $\begin{array}{l}\text { European } \\
\text { serin }\end{array}$ & Bizerte & $\begin{array}{l}\text { fimA-papC } \\
\text { aer }\end{array}$ & A & $\begin{array}{l}\text { ISEcp1-bla } \\
\text { CTX-M-15-orf477 }\end{array}$ & $\begin{array}{l}\text { NAL-C-SXT-TET- } \\
\text { STR-CIP }\end{array}$ & $\begin{array}{l}\text { tet(A), anrA1, anrB1, } \\
\operatorname{aac}\left(6^{\prime}\right) \mid b-c r, \operatorname{aac}(3) \|\end{array}$ & $\begin{array}{l}\mathrm{HI} 2, \mathrm{~W}, \\
\mathrm{FIC}, \mathrm{FIB} \\
\mathrm{P}\end{array}$ & P3 & New ST ${ }^{2}$ \\
\hline CbR35 & $\begin{array}{l}\text { European } \\
\text { serin }\end{array}$ & Bizerte & fimA-eae & A & $\begin{array}{l}\text { ISEcp1-bla } \\
\text { CTX-M-15-orf477 }\end{array}$ & $\begin{array}{l}\text { NAL-C-SXT-TET- } \\
\text { STR-CIP }\end{array}$ & $\begin{array}{l}\operatorname{tet}(A), \operatorname{anr} A 1, \operatorname{anr} B 1, \\
\operatorname{aac}(3) \|\end{array}$ & $\begin{array}{l}\mathrm{HIL}, \mathrm{W}, \\
\mathrm{FIC}, \mathrm{FIB} \\
\mathrm{P}, \mathrm{A} / \mathrm{C}\end{array}$ & P3 & New ST \\
\hline CbR37 & $\begin{array}{l}\text { European } \\
\text { serin }\end{array}$ & Bizerte & $\begin{array}{l}\text { fimA- } \\
\text { papC-aer }\end{array}$ & A & $\begin{array}{l}\text { ISEcp1-bla } \\
\text { CTX-M-15-orf477 }\end{array}$ & $\begin{array}{l}\text { NAL-C-SXT-TET- } \\
\text { STR-CIP }\end{array}$ & $\begin{array}{l}\text { bla TEM-1b, tet( }(A), \\
\text { anrA1, anrB1, } \\
\operatorname{aac}\left(6^{\prime}\right) \mid b-c r, \operatorname{aac}(3) \| l\end{array}$ & $\begin{array}{l}\text { HII, W, } \\
\text { FIC, FIB, } \\
P, A / C\end{array}$ & P3 & New ST \\
\hline CbR38 & $\begin{array}{l}\text { European } \\
\text { Greenfinch }\end{array}$ & Bizerte & $\begin{array}{l}\text { fimA-papC } \\
\text { aer }\end{array}$ & A & $\begin{array}{l}\text { ISEcp1-bla } \\
\text { CTX-M-15-orf477 }\end{array}$ & $\begin{array}{l}\text { NAL-C-SXT-TET- } \\
\text { STR-CIP }\end{array}$ & $\begin{array}{l}\operatorname{tet}(A), \operatorname{anr} A 1, \operatorname{anr} B 1 \text {, } \\
\operatorname{aac}\left(6^{\prime}\right) \mid b-c r, a a c(3) \|\end{array}$ & $\begin{array}{l}\mathrm{HI} 2, \mathrm{~W} \\
\mathrm{FIC}, \mathrm{FIB} \\
\mathrm{P}, \mathrm{A} / \mathrm{C}\end{array}$ & P3 & New ST ${ }^{2}$ \\
\hline CbR39 & $\begin{array}{l}\text { European } \\
\text { Goldfinch }\end{array}$ & Bizerte & $\operatorname{fimA-papC}$ & A & $\begin{array}{l}\text { ISEcp1-bla } \\
\text { CTX-M-15-orf477 }\end{array}$ & $\begin{array}{l}\text { NAL-C-SXT-TET- } \\
\text { STR-CIP }\end{array}$ & $\begin{array}{l}\text { bla } a_{\mathrm{TEM}-1 \mathrm{~b},} \text { tet }(A), \text { anrA1, } \\
\operatorname{qnr} B 1, a a c\left(6^{\prime}\right) \mid b-c r, \\
\operatorname{aac}(3) \|\end{array}$ & $\begin{array}{l}\mathrm{HI} 2, \mathrm{~W}, \\
\mathrm{FIC}, \mathrm{FIB} \\
\mathrm{P}, \mathrm{A} / \mathrm{C}\end{array}$ & P3 & New ST ${ }^{2}$ \\
\hline CbR40 & $\begin{array}{l}\text { European } \\
\text { Greenfinch }\end{array}$ & Bizerte & $\operatorname{fim} A$ & A & $\begin{array}{l}\text { ISEcp1-bla } \\
\text { CTX-M-15-orf477 }\end{array}$ & $\begin{array}{l}\text { NAL-C-SXT-TET- } \\
\text { STR-CIP }\end{array}$ & $\begin{array}{l}\text { bla TEM-1b, tet }(A), \\
\text { anrA }, \text { anrB1, aac(3)\| }\end{array}$ & $\begin{array}{l}\mathrm{HI} 2, \mathrm{~W}, \\
\mathrm{FIC}, \mathrm{FIB}, \\
\mathrm{P}, \mathrm{A} / \mathrm{C}\end{array}$ & P3 & New ST ${ }^{2}$ \\
\hline CbR44 & $\begin{array}{l}\text { Herring } \\
\text { Gulls }\end{array}$ & Bizerte & fimA-papC & A & $\begin{array}{l}\text { ISEcp1-bla } \\
\text { CTX-M-15-orf477 }\end{array}$ & $\begin{array}{l}\text { NAL-C-SXT-TET- } \\
\text { STR-CIP }\end{array}$ & $\begin{array}{l}\text { tet(A), anrA1, anrB1, } \\
\text { aac }\left(6^{\prime}\right) \mid b-c r, \operatorname{aac}(3) \|\end{array}$ & $\begin{array}{l}\mathrm{HI} 2, \mathrm{~W}, \\
\mathrm{FIC}, \mathrm{FIB}, \\
\mathrm{P}, \mathrm{A} / \mathrm{C}\end{array}$ & P3 & New ST ${ }^{c}$ \\
\hline Cb11 & $\begin{array}{l}\text { European } \\
\text { Goldfinch }\end{array}$ & Bizerte & fimA-papC & A & $\begin{array}{l}\text { ISEcp1-bla } \\
\text { CTX-M-15-orf477 }\end{array}$ & $\begin{array}{l}\text { NAL-C-SXT-TET- } \\
\text { STR-CIP }\end{array}$ & $\begin{array}{l}\text { bla TEM-1b, sul3, tet(A), } \\
\text { gnrA1, } \operatorname{anr} B 1, \operatorname{aac}(3) \|\end{array}$ & $\begin{array}{l}\mathrm{HI} 2, \mathrm{~W} \\
\mathrm{FIC}, \mathrm{A} / \mathrm{C}\end{array}$ & P3 & New ST ${ }^{2}$ \\
\hline Cb36 & $\begin{array}{l}\text { European } \\
\text { serin }\end{array}$ & Bizerte & fimA -aer & A & $\begin{array}{l}\text { ISEcp 1-bla } \\
\text { CTX-M-15 -orf477 }\end{array}$ & $\begin{array}{l}\text { NAL-C-SXT-TET- } \\
\text { STR-CIP }\end{array}$ & $\begin{array}{l}\operatorname{sul} 3, \operatorname{tet}(A), \operatorname{anr} B 1, \\
\operatorname{aac}(3) \|\end{array}$ & L/M, W & P2 & ST 297 \\
\hline Cb37 & $\begin{array}{l}\text { European } \\
\text { serin }\end{array}$ & Bizerte & $\begin{array}{l}\text { fimA- } \\
\text { papC-aer }\end{array}$ & A & $\begin{array}{l}\text { ISEcp1-bla } \\
\text { CTX-M-15-orf } 477\end{array}$ & $\begin{array}{l}\text { NAL-C-SXT-TET- } \\
\text { STR-CIP }\end{array}$ & $\begin{array}{l}\text { tet(A), anrB1, aac } \\
\left(6^{\prime}\right) \mid b-c r, \operatorname{aac}(3) \| l\end{array}$ & $\begin{array}{l}\mathrm{HI} 2, \mathrm{~W}, \\
\mathrm{FIC}, \mathrm{FIB}, \\
\mathrm{X}, \mathrm{A} / \mathrm{C}\end{array}$ & P4 & $\begin{array}{l}\text { New } \\
\mathrm{ST}^{\mathrm{b}}\end{array}$ \\
\hline Cb62 & $\begin{array}{l}\text { European } \\
\text { Goldfinch }\end{array}$ & $\begin{array}{l}\text { Menzel } \\
\text { Bouzalfa }\end{array}$ & $\operatorname{fim} A$ & A & $\begin{array}{l}\text { ISEcp 1-bla } \\
\text { CTX-M-15-orf } 477\end{array}$ & - & - & $\begin{array}{l}\mathrm{I1}, \mathrm{W}, \mathrm{FIC} \\
\mathrm{FIB}\end{array}$ & P1 & ST 410 \\
\hline Cb68 & $\begin{array}{l}\text { European } \\
\text { Bee-eaters }\end{array}$ & $\begin{array}{l}\text { Menzel } \\
\text { Bouzalfa }\end{array}$ & $\operatorname{fim} A$ & B2 & $\begin{array}{l}\text { ISEcp 1-bla } \\
\text { CTX-M-15-orf477 }\end{array}$ & - & - & $\mathrm{FIC}$ & P5 & ST 349 \\
\hline
\end{tabular}

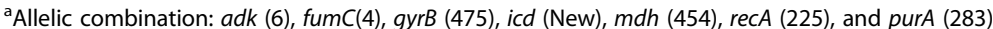

${ }^{\mathrm{b}}$ Allelic combination: adk (211), fumC(4), gyrB (4), icd (New), mdh (454), recA(225), and purA (283)

detected in only one isolate, was found in conjunction with fimA gene. The 12 ESBL-producing isolates were negative for the remaining virulence or serotype traits tested.

A significant variability in plasmid profiles among the 12 bla $_{\text {CTХ-M-15 }}$ E. coli isolates was observed and 7 different combinations have been shown (Table 3). IncF (FII, FIA, FIB) and IncW replicons were identified in 11 ESBL-producing strains, and in most cases, other replicons were also amplified: IncHI2 (9 strains), IncA/C (8 strains), IncP (7 strains) IncI1 (1 strain) and IncX (1 strain) (Table 3). The most prevalent replicon profiles identified were IncHI2 plus IncFIC plus IncFIB plus $\mathrm{IncW}$ plus Inc $\mathrm{P}$ plus IncA/C (six strains).

\section{Discussion}

Our study is the first report of ESBL-producing $E$. coli with the $b l a_{\mathrm{CTX}-\mathrm{M}-15}$ gene in wildlife in Tunisia and Africa. These results show a high percentage of faecal carriage of ESBL-producing $E$. coli isolates from wild birds (10.81\%) in samples obtained in 2012. Comparable prevalence was found in wild birds from various European countries where the detection rates varied between 8 to $16 \%[8,45-47]$. The first detection of ESBL-positive E. coli isolated from wild birds was reported since 2006 [48]. So far, Similar studies conducted in several European countries described a remarkable various percentage of ESBL carriage. Denmark and Poland were the least concerned countries with this phenomenon with $(0 \%)$ and $(0.7 \%)$ respectively. Spain (74.8\%) and Netherlands (37.8\%) constitutes the most two countries reporting high percentage of ESBL producing E. coli detected in wild birds, followed by Sweden (20.7\%), Latvia (17.4\%) and Portugal (12.7\%) [12]. 
The carriage rate of ESBL-producing E. coli observed in this current investigation is higher than the incidence of ESBL-isolates detected in faecal samples of healthy humans in Tunisia [21]. These findings are in agreement with the Chilean study, which demonstrated a high prevalence of ESBL-positive E. coli among the gulls (30.1\%) comparing to human population (12.2\%) [10]. This illustrates that ESBL E. coli producers are common not only in humans or livestock farming but also in wild birds.

Genotypic characterisation of all ESBL- positive E. coli showed the detection of bla $a_{\mathrm{CTX}-\mathrm{M}-15}$ gene. Previous studies reported that this gene, widely described in $E$. coli, is implicated in nosocomial human infections worldwide. These data are in coherence with the human situation in Tunisia, where bla $a_{\mathrm{CTX}-\mathrm{M}-15}$ is the most detected genotype in human clinical settings while $b l a_{\mathrm{CTX}}$ M-1 is most frequently detected among domestic animals $[22,24,25]$. This may suggest that the current carriage rate of ESBL $E$. coli producers found in wild bird is of anthropogenic nature. In the lack of other specific molecular data, we cannot exclude the possibility that the origin of the antibiotic resistance in some cases was not animal. It has indeed been recently shown that CTX-M15 producers begin to appear outside of Tunisian hospitals and colonize animals $[49,50]$.

Besides the production of CTX-M-15, we detected several other resistance determinants, including genes encoding resistance for tetracycline [tet $A]$, quinolones [qnrA1, qnrB1and aac(6')-Ib-cr], sulphonamides [sul3] and gentamicin $[a a c(3)-I I]$. Given the fact that wild bird aren't exposed to high doses of antibiotics, the resistance of their faecal flora is therefore directly acquired from their environment mirroring the dynamics of antimicrobial resistant bacteria in diverse ecological niches [11]. It is interesting to note that ESBL producing isolates recovered in the current study from free-living wild bird in urban area showed similar resistance phenotypes to those previously studied in human clinical settings in Tunisia. These facts probably indicate some human influence on the avian flora and might elucidate the acquisition and spread of antibiotic-resistant bacteria even without a direct antibiotic pressure [23]. Moreover, previous studies demonstrate that birds nesting near polluted waters harboured antibiotic-resistant $E$. coli with significantly higher frequencies than those associated with other environments. These results constitute a mirror of the potential role of human activity on the presence of antibiotic resistance genes in bird's territory $[51,52]$.

Classification based on plasmid incompatibility revealed that CTX-M-15 producing isolates recovered in the present study harboured several plasmids belonging to major plasmid replicon types including IncF, I1, HI2, $\mathrm{W}, \mathrm{X}, \mathrm{P}, \mathrm{L} / \mathrm{M}$ and $\mathrm{A} / \mathrm{C}$. IncF plasmids (FIA, FIB, FIC, and FII) were the most prevalent replicon types and were detected in 11 strains (91.7\%), similar to what has been reported in clinical data $[53,54]$. In accordance to previous studies, we recorded an extensively distribution of the IncF replicons which seems to be well adapted to $E$. coli species $[55,56]$. The bla $a_{C T X-M-15}$ gene has been frequently associated with IncF plasmids which could play a key role in promoting their rapid and global spread. [53, 56, 57].

The $\mathrm{A} / \mathrm{C}$ replicon was detected in 8 isolates $(66.7 \%)$, indeed this replicon has been considered to be widely common in Enterobacteriaceae and especially in E. coli isolates [58, 59].

Among the twelve $\mathrm{CTX}^{\mathrm{R}}$ E. coli, ten isolates carried both of bla $a_{\text {CTX-M-15 gene and PMQR genes, collected }}$ from five European serin, two Green birds, two Goldfinches, and one Herring gulls. These current findings showed that PMQR determinants were increasingly frequent in commensal isolates from wild birds in Tunisia. Previous studies emphasized that quinolone resistance is commonly associated to ESBL production highlighting that genes encoding resistance to beta-lactams and PMQR are frequently reported on the same mobile genetic element [6]. Interestingly, three PMQR determinants, qnrB1, qnrA1 and $a a c-\left(6^{\prime}\right)-I b-c r$, were detected in five different $E$. coli isolates. For all we know, the present study is the first report of these three PMQR determinants coexisting in an $E$. coli strain in Tunisia.

The enteropathogenic $E$. coli virulence factor eae was detected in one of the 12 CTX-M-15 producing isolates. It was isolated from European serin; this virulence gene was recently detected in a comparable frequency among ESBLpositive E. coli isolates of water samples in Tunisia [6].

The high prevalence of phylogenetic group A observed in this current study is in agreement with previous reports where commensal $E$. coli was found to be predominantly in phylogenetic groups A and B1 [21].

PFGE analysis highlighted similar macrorestriction patterns suggesting a clonal relationship for eight $E$. coli isolates; they were collected from four different bird species in the same city (Bizerte). Furthermore, Bizerte is a coastal city which combines several types of wild birds that shares the same source of water and feeding habits. It is likely that the eight multi-resistant CTX-M-15 harboring $E$. coli detected in this investigation is a result of clonal dissemination of successful clones even into an environment lacking antibiotic pressure.

The high carriage rate and modest genetic diversity of ESBLs producing E. coli from wild birds in Tunisia have also been reported in similar studies undertaken in The Netherlands, Spain and Germany, and might be explained by the existence of a common environmental source for the studied clonally related isolates $[8,15,45]$.

The ESBL-producing E. coli. STs present in avian fecal samples from this study included ST297, and ST349 
appear to be common types in isolates from animal and environmental origin $[60,61]$. Interestingly, the CTX-M15-producing Escherichia coli isolates of lineages ST410-A identified in this study was previously reported in wildlife, humans, animals and environment [62-66]. This finding demonstrates successful transmission of clone ST410 E. coli between different hosts and ecosystems.

\section{Conclusion}

To our knowledge, this study provides the first insight into the contribution of wild birds to the dynamics of ESBL-producing E. coli in Tunisia. Multidrug resistance bacteria transmission through avian mobility is still poorly understood and requires the implementation of several monitoring and control strategies.

\section{Abbreviations}

CHL: Chloramphenicol; CIP: Ciprofloxacin; CTX: Cefotaxime; CTXR: Cefotaxime resistant; ESBL: Extended spectrum $\beta$-lactamase; MLST: Multilocus sequence typing; NAL: Nalidixic acid; PFGE: Pulsed-field gel electrophoresis; PMQR: Plasmidmediated quinolone resistance; QRDR: Quinolone resistance-determining regions; STR: Streptomycin; SXT: Sulfamethoxazole-trimethoprim; TET: Tetracycline

\section{Acknowledgements}

The authors gratefully acknowledge support of Tunisian Ministry of Agriculture and the Institute of Veterinary Research of Tunisia.

\section{Funding}

The experimental part was performed in the University of Tunis El Manar in Microorganisms and Active Biomolecules Laboratory (Ref. LR03ES03). This work was supported by the Tunisian Ministry of Higher Education and Scientific Research. Rym BEN SALLEM has a postdoctoral fellowship of I'Oréal-UNESCO for women in science program.

\section{Availability of data and materials}

All the data generated in this current work are included in the 'Result'.

\section{Authors' contributions}

KBS and HBY: designed the study; KBS, NK and AB: coordinated and supervised the study; HBY, GT and IBA: performed the lab experiments; HBY, RBS and KBS: wrote the manuscript; HBY, RBS, HG and KBS: participate in analyses of the data and in the manuscript revision. All the authors read and approved the final version of the manuscript.

\section{Ethics approval and consent to participate}

The sampling was carried out in collaboration with researchers from the Tunisian veterinary research institute as part of a specific surveillance program on avian influenza. A written permission to perform the avian fecal sampling on the sites visited was issued from The Ministry of Agriculture of Tunisia and sampling protocol was reviewed and approved by the local Research Ethics Committee prior to the initiation of the research (Authorisation number: 1213). The authors state the compliance with general rules of research ethics involving animals. We specify that we did not handle the birds.

\section{Consent for publication}

Not applicable.

\section{Competing interests}

The authors declare that they have no competing interests.

\section{Publisher's Note}

Springer Nature remains neutral with regard to jurisdictional claims in published maps and institutional affiliations.
Received: 8 May 2017 Accepted: 15 March 2018

Published online: 02 April 2018

\section{References}

1. Sorum $H$, Sunde M. Resistance to antibiotics in the normal flora of animals. Vet Res. 2001;32(3-4):227-41.

2. EFSA: European Food Safety Authority 2012. The European Union summary report on antimicrobial resistance in zoonotic and indicator bacteria from humans, animals and food in 2010. EFSA J. 2012;10:2598.

3. van den Bogaard $A E$, Stobberingh EE. Epidemiology of resistance to antibiotics. Links between animals and humans. Int J Antimicrob Agents. 2000;14(4):327-35

4. Livermore DM. Current epidemiology and growing resistance of gramnegative pathogens. Korean J Internal Med. 2012;27(2):128-42.

5. Coque TM, Novais A, Carattoli A, Poirel L, Pitout J, Peixe L, Baquero F, Canton R, Nordmann P. Dissemination of clonally related Escherichia coli strains expressing extended-spectrum beta-lactamase CTX-M-15. Emerg Infect Dis. 2008;14(2):195-200.

6. Ben Said L, Jouini A, Alonso CA, Klibi N, Dziri R, Boudabous A, Ben Slama K, Torres C. Characteristics of extended-spectrum beta-lactamase (ESBL)- and pAmpC beta-lactamase-producing Enterobacteriaceae of water samples in Tunisia. Sci Total Environ. 2016:550:1103-9.

7. Hasan B, Olsen B, Alam A, Akter L, Melhus A. Dissemination of the multidrug-resistant extended-spectrum beta-lactamase-producing Escherichia coli O25b-ST131 clone and the role of house crow (Corvus splendens) foraging on hospital waste in Bangladesh. Clin Microbiol. 2015; 21(11):1000. e1001-1004

8. Veldman K, van Tulden P, Kant A, Testerink J, Mevius D. Characteristics of cefotaxime-resistant Escherichia coli from wild birds in the Netherlands. Appl Environ Microbiol. 2013;79(24):7556-61.

9. Literak I, Dolejska M, Janoszowska D, Hrusakova J, Meissner W, Rzyska H, Bzoma S, Cizek A. Antibiotic-resistant Escherichia coli bacteria, including strains with genes encoding the extended-spectrum beta-lactamase and QnrS, in waterbirds on the Baltic Sea coast of Poland. Appl Environ Microbiol. 2010;76(24):8126-34.

10. Hernandez J, Johansson A, Stedt J, Bengtsson S, Porczak A, Granholm S, Gonzalez-Acuna D, Olsen B, Bonnedahl J, Drobni M. Characterization and comparison of extended-spectrum beta-lactamase (ESBL) resistance genotypes and population structure of Escherichia coli isolated from Franklin's gulls (Leucophaeus pipixcan) and humans in Chile. PLoS One. 2013:8(9):e76150.

11. Allen KJ, Lepp D, McKellar RC, Griffiths MW. Targeted microarray analysis of stationary phase Escherichia coli 0157:H7 subjected to disparate nutrient conditions. J Appl Microbiol. 2010;109(6):2118-27.

12. Stedt J, Bonnedahl J, Hernandez J, Waldenstrom J, McMahon BJ, Tolf C, Olsen B, Drobni M. Carriage of CTX-M type extended spectrum betalactamases (ESBLs) in gulls across Europe. Acta Vet Scand. 2015;57:74.

13. Poeta P, Radhouani H, Igrejas G, Goncalves A, Carvalho C, Rodrigues J, Vinue L, Somalo S, Torres C. Seagulls of the Berlengas natural reserve of Portugal as carriers of fecal Escherichia coli harboring CTX-M and TEM extendedspectrum beta-lactamases. Appl Environ Microbiol. 2008;74(23):7439-41.

14. Pinto L, Radhouani H, Coelho C, Martins da Costa P, Simoes R, Brandao RM, Torres C, Igrejas G, Poeta P. Genetic detection of extended-spectrum betalactamase-containing Escherichia coli isolates from birds of prey from Serra da Estrela natural Reserve in Portugal. Appl Environ Microbiol. 2010;76(12):4118-20.

15. Guenther S, Grobbel M, Beutlich J, Bethe A, Friedrich ND, Goedecke A Lubke-Becker A, Guerra B, Wieler LH, Ewers C. CTX-M-15-type extendedspectrum beta-lactamases-producing Escherichia coli from wild birds in Germany. Environ Microbiol Rep. 2010;2(5):641-5.

16. WHO: Critically important antimicrobials for human medicine: categorization for the development of risk management strategies to contain antimicrobia resistance due to nonhuman antimicrobial use. Report of the second WHO Expert Meeting, Copenhagen, 29 to 31 May 2007 World Health Organization, Geneva, Switzerland. 2007. http://apps.who.int/iris/bitstream/ handle/10665/43765/9789241595742 eng.pdf?sequence $=1$.

17. Alonso CA, Zarazaga M, Ben Sallem R, Jouini A, Ben Slama K, Torres C. Antibiotic resistance in Escherichia coli in husbandry animals: the African perspective. Lett Appl Microbiol. 2017;64(5):318-34.

18. Ben Said L, Jouini A, Klibi N, Dziri R, Alonso CA, Boudabous A, Ben Slama K, Torres C. Detection of extended-spectrum beta-lactamase (ESBL)-producing 
Enterobacteriaceae in vegetables, soil and water of the farm environment in Tunisia. Int J Food Microbiol. 2015;203:86-92.

19. Ben Sallem R, Ben Slama K, Rojo-Bezares B, Porres-Osante N, Jouini A, Klibi N, Boudabous A, Saenz Y, Torres C. Incl1 plasmids carrying Bla(CTX-M-1) or Bla(CMY-2) genes in Escherichia coli from healthy humans and animals in Tunisia. Microb Drug Resist. 2014;20(5):495-500.

20. Jouini A, Slama KB, Klibi N, Sallem RB, Estepa V, Vinue L, Saenz Y, Ruiz-Larrea $F$, Boudabous $A$, Torres $C$. Lineages and virulence gene content among extended-spectrum beta-lactamase-producing Escherichia coli strains of food origin in Tunisia. J Food Prot. 2013;76(2):323-7.

21. Ben Sallem R, Ben Slama K, Estepa V, Jouini A, Gharsa H, Klibi N, Saenz Y, RuizLarrea F, Boudabous A, Torres C. Prevalence and characterisation of extendedspectrum beta-lactamase (ESBL)-producing Escherichia coli isolates in healthy volunteers in Tunisia. Eur J Clin Microbiol Infect Dis. 2012;31(7):1511-6.

22. Ben Sallem R, Ben Slama K, Saenz Y, Rojo-Bezares B, Estepa V, Jouini A, Gharsa H, Klibi N, Boudabous A, Torres C. Prevalence and characterization of extended-spectrum beta-lactamase (ESBL)- and CMY-2-producing Escherichia coli isolates from healthy food-producing animals in Tunisia. Foodborne Pathog Dis. 2012;9(12):1137-42.

23. Ben Slama K, Ben Sallem R, Jouini A, Rachid S, Moussa L, Saenz Y, Estepa V, Somalo S, Boudabous A, Torres C. Diversity of genetic lineages among CTXM-15 and CTX-M-14 producing Escherichia coli strains in a Tunisian hospital. Curr Microbiol. 2011;62(6):1794-801.

24. Ben Slama K, Jouini A, Ben Sallem R, Somalo S, Saenz Y, Estepa V, Boudabous A, Torres C. Prevalence of broad-spectrum cephalosporinresistant Escherichia coli isolates in food samples in Tunisia, and characterization of integrons and antimicrobial resistance mechanisms implicated. Int J Food Microbiol. 2010;137(2-3):281-6.

25. Jouini A, Vinue L, Slama KB, Saenz Y, Klibi N, Hammami S, Boudabous A, Torres C. Characterization of CTX-M and SHV extended-spectrum betalactamases and associated resistance genes in Escherichia coli strains of food samples in Tunisia. J Antimicrob Chemother. 2007;60(5):1137-41.

26. Klibi N, Ben Amor I, Rahmouni M, Dziri R, Douja G, Ben Said L, Lozano C, Boudabous A, Ben Slama K, Mansouri R, et al. Diversity of species and antibiotic resistance among fecal enterococci from wild birds in Tunisia. Detection of vanAcontaining enterococcus faecium isolates. Eur J Wildlife Res. 2015;61(2):319-23.

27. CLSI. Performance standards for antimicrobial susceptibility testing; twentyfifth informational supplement. Wayne: Clinical and Laboratory Standards Institute; 2015. p. M100-S25.

28. Tenover FC, Arbeit RD, Goering RV, Mickelsen PA, Murray BE, Persing DH, Swaminathan B. Interpreting chromosomal DNA restriction patterns produced by pulsed-field gel electrophoresis: criteria for bacterial strain typing. J Clin Microbiol. 1995;33(9):2233-9.

29. Saenz Y, Brinas L, Dominguez E, Ruiz J, Zarazaga M, Vila J, Torres C. Mechanisms of resistance in multiple-antibiotic-resistant Escherichia coli strains of human, animal, and food origins. Antimicrob Agents Chemother. 2004;48(10):3996-4001.

30. Tartof SY, Solberg OD, Manges AR, Riley LW. Analysis of a uropathogenic Escherichia coli clonal group by multilocus sequence typing. J Clin Microbiol. 2005:43(12):5860-4.

31. Clermont $\mathrm{O}$, Bonacorsi $\mathrm{S}$, Bingen E. Rapid and simple determination of the Escherichia coli phylogenetic group. Appl Environ Microbiol. 2000;66(10):4555-8.

32. Clermont O, Lavollay M, Vimont S, Deschamps C, Forestier C, Branger C, Denamur E, Arlet G. The CTX-M-15-producing Escherichia coli diffusing clone belongs to a highly virulent B2 phylogenetic subgroup. J Antimicrob Chemother. 2008;61(5):1024-8.

33. Blanco M, Alonso MP, Nicolas-Chanoine MH, Dahbi G, Mora A, Blanco JE, Lopez C, Cortes P, Llagostera M, Leflon-Guibout V, et al. Molecular epidemiology of Escherichia coli producing extended-spectrum \{beta\}lactamases in Lugo (Spain): dissemination of clone O25b:H4-ST131 producing CTX-M-15. J Antimicrob Chemother. 2009;63(6):1135-41.

34. Ruiz J, Simon K, Horcajada JP, Velasco M, Barranco M, Roig G, Moreno-Martinez A, Martinez JA, Jimenez de Anta T, Mensa J, et al. Differences in virulence factors among clinical isolates of Escherichia coli causing cystitis and pyelonephritis in women and prostatitis in men. J Clin Microbiol. 2002;40(12):4445-9.

35. Vinue L, Lantero M, Saenz Y, Somalo S, de Diego I, Perez F, Ruiz-Larrea F, Zarazaga M, Torres C. Characterization of extended-spectrum betalactamases and integrons in Escherichia coli isolates in a Spanish hospital. J Med Microbiol. 2008:57(Pt 7):916-20.

36. van de Klundert JA, Vliegenthart JS. Nomenclature of aminoglycoside resistance genes: a comment. Antimicrob Agents Chemother. 1993;37(4): 927-8.
37. Cattoir $V$, Poirel L, Nordmann P. In-vitro mutagenesis of qnrA and qnrS genes and quinolone resistance in Escherichia coli. Clin Microbiol Infect. 2007;13(9):940-3.

38. Rocha-Gracia R, Ruiz E, Romero-Romero S, Lozano-Zarain P, Somalo S, Palacios-Hernandez JM, Caballero-Torres P, Torres C. Detection of the plasmid-borne quinolone resistance determinant qepA1 in a CTX-M-15producing Escherichia coli strain from Mexico. J Antimicrob Chemother. 2010;65(1):169-71.

39. Wang A, Yang Y, Lu Q, Wang Y, Chen Y, Deng L, Ding H, Deng Q, Zhang H, Wang $C$, et al. Presence of qnr gene in Escherichia coli and Klebsiella pneumoniae resistant to ciprofloxacin isolated from pediatric patients in China. BMC Infect Dis. 2008;8:68.

40. Vila J, Ruiz J, Goni P, De Anta MT. Detection of mutations in parC in quinolone-resistant clinical isolates of Escherichia coli. Antimicrob Agents Chemother. 1996;40(2):491-3.

41. Oram M, Fisher LM. 4-quinolone resistance mutations in the DNA gyrase of Escherichia coli clinical isolates identified by using the polymerase chain reaction. Antimicrob Agents Chemother. 1991;35(2):387-9.

42. Saenz Y, Zarazaga M, Brinas L, Ruiz-Larrea F, Torres C. Mutations in gyrA and parC genes in nalidixic acid-resistant Escherichia coli strains from food products, humans and animals. J Antimicrob Chemother. 2003;51(4):1001-5.

43. Martinez FF, Carabias ML, Izquierdo Jl, Centelles ML, Prieto JP. Comparison of the in vitro and in vivo effects of meropenem and ciprofloxacin on the morphology of Escherichia coli and Staphylococcus aureus. Revista espanola de quimioterapia : publicacion oficial de la Sociedad Espanola de Quimioterapia. 1998;11(3):238-44.

44. Carattoli A, Bertini A, Villa L, Falbo V, Hopkins KL, Threlfall EJ. Identification of plasmids by PCR-based replicon typing. J Microbiol Methods. 2005;63(3):219-28.

45. Alcala L, Alonso CA, Simon C, Gonzalez-Esteban C, Oros J, Rezusta A, Ortega C, Torres C. Wild birds, frequent carriers of extended-Spectrum betalactamase (ESBL) producing Escherichia coli of CTX-M and SHV-12 types. Microb Ecol. 2015;

46. Guenther S, Aschenbrenner K, Stamm I, Bethe A, Semmler T, Stubbe A, Stubbe M, Batsajkhan N, Glupczynski Y, Wieler LH, et al. Comparable high rates of extended-spectrum-beta-lactamase-producing Escherichia coli in birds of prey from Germany and Mongolia. PLoS One. 2012;7(12):e53039.

47. Guenther S, Ewers C, Wieler LH. Extended-Spectrum Beta-lactamases Producing E. Coli in wildlife, yet another form of environmental pollution? Front Microbiol. 2011;2:246.

48. Costa D, Poeta P, Saenz Y, Vinue L, Rojo-Bezares B, Jouini A, Zarazaga M, Rodrigues J, Torres C. Detection of Escherichia coli harbouring extendedspectrum beta-lactamases of the CTX-M, TEM and SHV classes in faecal samples of wild animals in Portugal. J Antimicrob Chemother. 2006;58(6):1311-2.

49. Grami R, Dahmen S, Mansour W, Mehri W, Haenni M, Aouni M, Madec JY. blaCTX-M-15-carrying F2:A-:B- plasmid in Escherichia coli from cattle milk in Tunisia. Microb Drug Resist. 2014;20(4):344-9.

50. Kilani H, Abbassi MS, Ferjani S, Mansouri R, Sghaier S, Ben Salem R, Jaouani I, Douja G, Brahim S, Hammami S, et al. Occurrence of Bla CTX-M-1, qnrB1 and virulence genes in avian ESBL-producing Escherichia coli isolates from Tunisia. Front Cell Infect Microbiol. 2015;5:38.

51. Cole D, Drum DJ, Stalknecht DE, White DG, Lee MD, Ayers S, Sobsey M, Maurer JJ. Free-living Canada geese and antimicrobial resistance. Emerg Infect Dis. 2005;11(6):935-8.

52. Dolejska M, Cizek A, Literak I. High prevalence of antimicrobial-resistant genes and integrons in Escherichia coli isolates from black-headed gulls in the Czech Republic. J Appl Microbiol. 2007;103(1):11-9.

53. Sherley M, Gordon DM, Collignon PJ. Species differences in plasmid carriage in the Enterobacteriaceae. Plasmid. 2003;49(1):79-85.

54. Boyd EF, Hill CW, Rich SM, Hartl DL. Mosaic structure of plasmids from natural populations of Escherichia coli. Genetics. 1996;143(3):1091-100.

55. Poirel L, Bonnin RA, Nordmann P. Genetic support and diversity of acquired extended-spectrum beta-lactamases in gram-negative rods. Infect Genet Evol. 2012;12(5):883-93.

56. Carattoli A. Resistance plasmid families in Enterobacteriaceae. Antimicrob Agents Chemother. 2009;53(6):2227-38.

57. Johnson TJ, Wannemuehler YM, Johnson SJ, Logue CM, White DG, Doetkott C, Nolan LK. Plasmid replicon typing of commensal and pathogenic Escherichia coli isolates. Appl Environ Microbiol. 2007;73(6):1976-83.

58. Guo Y-F, Zhang W-H, Ren S-Q, Yang L, Lü D-H, Zeng Z-L, Liu Y-H, Jiang H-X. IncA/C plasmid-mediated spread of CMY-2 in multidrug-resistant Escherichia coli from food animals in China. PLoS One. 2014;9(5):e96738. 
59. Lindsey RL, Fedorka-Cray PJ, Frye JG, Meinersmann RJ. Inc A/C Plasmids Are Prevalent in Multidrug-Resistant Salmonella enterica Isolates. Appl Environ Microbiol. 2009;75(7):1908-15.

60. Araujo S, AT Silva I, Tacao M, Patinha C, Alves A, Henriques I. Characterization of antibiotic resistant and pathogenic Escherichia coli in irrigation water and vegetables in household farms. Int J Food Microbiol. 2017;257:192-200.

61. Maamar E, Hammami S, Alonso CA, Dakhli N, Abbassi MS, Ferjani S, Hamzaoui Z, Saidani M, Torres C, Boutiba-Ben Boubaker I. High prevalence of extendedspectrum and plasmidic AmpC beta-lactamase-producing Escherichia coli from poultry in Tunisia. Int J Food Microbiol. 2016;231:69-75.

62. Schaufler K, Semmler T, Wieler LH, Wohrmann M, Baddam R, Ahmed N, Muller K, Kola A, Fruth A, Ewers C, et al. Clonal spread and interspeciestransmission of clinically relevant ESBL-producing Escherichia coli of ST410 - another successful pandemic clone? FEMS Microbiol Ecol. 2016:92(1):fiv155. https://doi.org/10.1093/femsec/fiv155.

63. Ben Sallem R, Ben Slama K, Estepa V, Cheikhna EO, Mohamed AM, Chairat S, RuizLarrea F, Boudabous A, Torres C. Detection of CTX-M-15-producing Escherichia coli isolates of lineages ST410-a, ST617-a and ST354-D in faecal samples of hospitalized patients in a Mauritanian hospital. J Chemother. 2015;27(2):114-6.

64. Soufi L, Saenz Y, Vinue L, Abbassi MS, Hammami S, Torres C. Characterization of pc promoter variants of class 1 integrons in Escherichia coli isolates from poultry meat. Foodborne Pathog Dis. 2013;10(12):1075-7.

65. Silva KC, Moreno M, Cabrera C, Spira B, Cerdeira L, Lincopan N, Moreno AM. First characterization of CTX-M-15-producing Escherichia coli strains belonging to sequence type (ST) 410, ST224, and ST1284 from commercial swine in South America. Antimicrob Agents Chemother. 2016;60(4):2505-8.

66. Lopez-Cerero L, Egea P, Serrano L, Navarro D, Mora A, Blanco J, Doi Y, Paterson DL, Rodriguez-Bano J, Pascual A. Characterisation of clinical and food animal Escherichia coli isolates producing CTX-M-15 extendedspectrum beta-lactamase belonging to ST410 phylogroup a. Int J Antimicrob Agents. 2011;37(4):365-7.

\section{Submit your next manuscript to BioMed Central and we will help you at every step:}

- We accept pre-submission inquiries

- Our selector tool helps you to find the most relevant journal

- We provide round the clock customer support

- Convenient online submission

- Thorough peer review

- Inclusion in PubMed and all major indexing services

- Maximum visibility for your research

Submit your manuscript at www.biomedcentral.com/submit 